\title{
Influence of soil compaction on the growth of silver fir (Abies alba Mill.) under a forest canopy
}

\author{
Mariusz Kormanek ${ }^{1}$ Jacek Banach², Dawid Leńczuk ${ }^{1}$ \\ ${ }^{1}$ Institute of Forest Utilization and Forest Technology, Department of Forest Work Mechanisation, \\ University of Agriculture in Kraków, Al. 29 Listopada 46, 31-423 Kraków, Poland \\ e-mail: rlkorma@cyf-kr.edu.pl \\ ${ }^{2}$ Institute of Forest Ecology and Silviculture, Department of Genetics and Forest Tree Breeding, \\ University of Agriculture in Kraków, Al. 29 Listopada 46, 31-423 Kraków, Poland
}

\begin{abstract}
In the study, the influence of soil compaction on the growth of silver fir seedlings (Abies alba Mill.) was evaluated; the soil compaction being measured using a cone penetrometer. The studies were conducted under a forest canopy, where the exploratory units with different soil compactions exerting a unit pressure of $50,100,150,200$, and $250 \mathrm{kPa}$, as well as the control units (without pressure), were prepared. Selected units were sown with seeds of silver fir, and from the remaining units, the soil samples were collected and their compaction measured using a cone penetrometer. After 5 months, the seedlings were collected and their growth analyzed. Increasing the unit pressure resulted in soil compaction characterized by the compaction in the layer up to $15 \mathrm{~cm}$, in which the roots of the growing seedlings were found. Different variants of the pressure significantly affected the analyzed parameters of seedlings. Negative and statistically significant correlation was reported between increasing compaction of the soil, the length of the primary root, and the total length of seedlings $(-0.46$ and -0.35 , respectively), while the positive correlation was found for the length of the stem (+0.32). Similarly, there was a statistically significant negative correlation between the increased soil compaction and the dry weight of the root system (-0.29), and positive correlation in the case of the stem dry weight $(0.26)$. Increasing soil compaction, however, did not affect significantly the size of assimilation apparatus.
\end{abstract}

Keywords: compaction, pressure compaction unit, seedling, silver fir.

\section{Introduction}

A number of abiotic factors, particularly light, fertilization, and water availability, determine the growth of forest trees (Sack 2004; Bejarano et al. 2010). It also depends on many factors related to physical properties of a soil, i.e., an excessive soil compaction (Pérez-Ramos et al. 2010; Alameda et al. 2012). Compaction increases the bulk density and resistance during soil penetration and reduces the size of voids, i.e., its porosity, which reduces the permeability and water flow, as well as air saturation (Blouin et al. 2008; Bejarano et al. 2010; Lipiec et al. 2012).

Very compacted soil may cause that plant require more energy for growth, especially for the development of root system. Moreover, soil compaction promotes shallow-root- ed plants (Kozlowski 1999) and change in the morphological characteristics of the roots (Lipiec et al. 2012), which may affect their stability (Ulrich et al. 2003). Effects of excessive soil compaction depends on the type of the soil, its $\mathrm{pH}$, cation exchange, groundwater level, organic matter content, climate, and the level of initial soil compaction (Kozlowski 1999; Ulrich et al. 2003; Blouin et al. 2008). Soils compact both naturally and because of human actions and trampling by animals as well (Kozlowski 1999). Loose soils may be compacted by subsidence and landslides, particulary when the soil is well moisturized. Compaction as a result of human activity, on the one hand, is associated with the process of soil growing, and, on the other hand, with the passing of machines (Picchio et al. 2012). Most of the ground damage in the forest results from passing of 
heavy machines, in particular performing logging, and this damage are formed in the immediate vicinity of skidding, reaching deeper into the soil profile to a depth of even 70 $\mathrm{cm}$. The growth of trees up to $15 \mathrm{~m}$ on both sides of the strip logging may be reduced from 10 to $15 \%$, and often by even greater proportion (Ulrich et al. 2003). The determination of the growth of different forest tree species seedlings on the compacted soil is important not only from the viewpoint of the costs incurred to prepare the ground for the forestation, but also due to the costs incurred for refilling during planting of seedlings. Undoubtedly, unfavorable soil conditions also have an impact on the health and productivity of the forest, which grows from seedlings grown in unfavorable conditions (Kozlowski 1999).

The soil compaction measured using a cone penetrometer is the parameter that is commonly used as a measure of the soil compactness (Dexter et al. 2007)

There is little information regarding the effects of soil compaction on forest tree seedlings species growth. Previous studies carried out for Scots pine (Pinus sylvestris L.) and pedunculate oak (Quercus robur L.) showed that such a relationship exists (Kormanek \& Banach 2012). However, each species may have its own preferences as indicated by several studies that analyzed the effect of compactness of the nursery ground on the growth of seedlings (Conlin \& van den Driessche 1996; Maupin \& Struve 1997; Zahreddine et al. 2004; Kormanek et al. 2013). It is therefore necessary to carry out further research in this area, especially for silver fir (Abies alba Mill.), which renews itself naturally through self-seeding. The objective of the study is to determine the effect of soil compaction on the growth of silver fir (Abies alba Mill.) seedlings growing on the stand under canopy.

\section{Study area}

The research was made in the forest, located within forest nursery "Kłaj" (the Niepołomice Forest District). The experiment was set on the flat area on sandy loam soil (Table 1) on the fresh mixed deciduous forest type habitat (FMDF) (PTG 2008).

\section{Materials and methods}

Different level of soil compaction was artificially induced by static pressure applied on the soil. The value of soil compaction was determined using penetration resistance parameter, gravimetric moisture content and soil density parameters.

In the study, a self-developed device, installed on the three-point tractor's system, for the controlled pressure exerted on the ground was used (Kormanek 2013), by which pressure was exerted on the soil by flat wooden stamp with dimensions of $25 \times 25 \mathrm{~cm}$. Every single exploratory unit corresponded to the dimension of the stamp. Different pressure values of 50 (P1), 100 (P2), 150 (P3), 200 (P4), and $250 \mathrm{kPa}$ (P5) were used in the study; the control units (P0) on which no pressure was exerted were also established with the dimensions of $12.5 \times 25 \mathrm{~cm}$. During the selection of the pressure values, the pressure exerted by elements of suspension and steering of machines working in the forest within the applied range were recommended (Ulrich et al. 2003).

Pressure application time was 10 seconds and it corresponded to the time of exerting the pressure by the sixwheel drive machine passing once at a velocity of approximately $6 \mathrm{~km} \cdot \mathrm{h}^{-1}$ (e.g., forwarder or a farm tractor equipped with a logging trailer) for which the contact surface between a wheel and a soil is related to the surface of the exploratory unit.

In the research area, a total of 30 study plots $(25 \times$ $25 \mathrm{~cm}$ ) were used, such as 3 sets per 5 units of different variants of unit pressure $(\mathrm{P} 1-\mathrm{P} 5)$ and 3 sets per 5 control units $(12.5 \times 25 \mathrm{~cm})(\mathrm{P} 0)$, located at the side to the plots on which the pressure was exerted.

Between individual variants of study plots it was prepared the additional sets of plot samples. On each of these plots it was measured the penetration resistance up to a depth of $31.5 \mathrm{~cm}$, using self-developed static cone penetrometer with a resolution of $1.5 \mathrm{~cm}$ (Kormanek 2011), and were collected soil samples from the layer of up to 15 $\mathrm{cm}$ deep into $250 \mathrm{~cm}^{3}$ measuring cylinders. On the basis of soil samples gravimetric moisture content and volume density were calculated.

In the study, a standard normalized cone with a base diameter of $1.27 \mathrm{~cm}$ (0.5 inch) was used (ASAE Standards 1998), which was manually introduced into the soil at a velocity of approximately $3 \mathrm{~cm} \cdot \mathrm{s}^{-1}$.

In units where the pressure was applied, 10 seeds of silver fir were sown $(25 \times 25 \mathrm{~cm}$ plot $)$, and on the control units, 5 seeds (May 4th, 2013) were sown $(12.5 \times 25 \mathrm{~cm}$ plot), which were then covered with a layer of peat substrate with a thickness of approximately $2-3 \mathrm{~cm}$ according to recommendations for this species (Sobczak 1992). The seeds used in the experiment were derived from selected seed stands in Powroźnik forest range (Forest Experimental Station Krynica-Zdrój) and collected in September 2012.

During the growing season, no treatments were performed so that the plants could grow in conditions which are the most natural possible. After 5 months (October 8th) seedlings with some chunk of land were dug, collecting the entire experimental units. The chunk of land was steeped in water to collect single seedlings without damaging their root systems. For each seedling, the length of the steam and primary root were measured with an accuracy of \pm 1 $\mathrm{mm}$ and the diameter of the root collar with an accuracy of 
Table 1. Soil texture and share of organic substances at measuring stand

\begin{tabular}{|c|c|c|c|c|c|c|c|c|}
\hline \multirow{2}{*}{$\begin{array}{c}\text { Depth } \\
{[\mathrm{cm}]}\end{array}$} & \multirow{2}{*}{$\begin{array}{c}\text { Sand } \\
{[\%]}\end{array}$} & \multirow{2}{*}{$\begin{array}{l}\text { Silt } \\
{[\%]}\end{array}$} & \multirow{2}{*}{$\begin{array}{c}\text { Loam } \\
{[\%]}\end{array}$} & $\mathrm{N}$ & $\mathrm{C}$ & \multirow{2}{*}{$\mathrm{C} / \mathrm{N}$} & \multicolumn{2}{|c|}{$\mathrm{pH}$ in } \\
\hline & & & & \multicolumn{2}{|c|}{$[\%]$} & & $\mathrm{H}_{2} \mathrm{O}$ & $\mathrm{KCL}$ \\
\hline $0-10$ & 76 & 19 & 5 & 0.249 & 4.798 & 19.28 & 4.10 & 3.33 \\
\hline $10-20$ & 83 & 13 & 4 & 0.063 & 1.598 & 25.41 & 4.41 & 3.83 \\
\hline $20-30$ & 83 & 14 & 3 & 0.022 & 0.675 & 30.08 & 4.62 & 4.22 \\
\hline
\end{tabular}

Table 2. Average values $( \pm \mathrm{SD})$ for physical and mechanical parameters of a soil in subsequent variants of the exerted pressure; $0-15 \mathrm{~cm}$ soil layer

\begin{tabular}{|c|c|c|c|}
\hline Measurement variant & $\begin{array}{c}\text { Gravimetric moisture content } \\
\left(\mathrm{g} \cdot \mathrm{g}^{-1}\right)\end{array}$ & $\begin{array}{c}\text { Volumetric density } \\
\left(\mathrm{g} \cdot \mathrm{cm}^{-3}\right)\end{array}$ & $\begin{array}{c}\text { Soil compaction } \\
(\mathrm{MPa})\end{array}$ \\
\hline P0 & $0.447 \pm 0.145$ & $0.482 \pm 0.011$ & $0.330 \pm 0.103$ \\
\hline P1 & $0.597 \pm 0.096$ & $0.560 \pm 0.011$ & $0.438 \pm 0.124$ \\
\hline P2 & $0.523 \pm 0.015$ & $0.593 \pm 0.010$ & $0.482 \pm 0.102$ \\
\hline P3 & $0.366 \pm 0.025$ & $0.601 \pm 0.016$ & $0.480 \pm 0.108$ \\
\hline P4 & $0.280 \pm 0.024$ & $0.649 \pm 0.035$ & $0.498 \pm 0.110$ \\
\hline P5 & $0.299 \pm 0.039$ & $0.713 \pm 0.019$ & \\
\hline
\end{tabular}

$\pm 0.01 \mathrm{~mm}$. In order to determine the surface of assimilation apparatus, needles from each seedling were removed, followed by scanning using STD 1600+ scanner.

For a single seedling, the number of needles and their surface were determined using Winseedle (Regent Instruments Inc., Quebec, Canada). Seedlings were then dried at $70^{\circ} \mathrm{C}$ for 48 hours and the dry weight of the underground part, stem, and assimilation apparatus were determined with an accuracy of $\pm 0.001 \mathrm{~g}$.

The obtained results were subjected to statistical analysis using Statistica 10.0 (Stat Soft Inc.). The mean values of the analyzed variables were calculated, analysis of variance was performed, and identification of homogeneous groups using Tukey's multiple comparison test was conducted. For parameters with a significant variation, regression analysis using compaction was performed.

\section{Results and discussion}

In the experiment, a total of 70 seedlings were grown from 225 fir seeds sown. The average yield of sowing in all experimental variants was estimated at $31.1 \%$, which exceeds the performance of seeding for this species in nursery conditions within the range of 14-20\% (Sobczak 1992).

Change of compaction (Fig. 1) and the physical parameters of a soil in subsequent variants of measurement (Table 2) indicate that the exerted unit pressure affect- ed primarily the compaction of the soil in a layer up to a depth of $15 \mathrm{~cm}$, i.e., the zone in which the root systems of young plants occurred, although the scope of changes reached deeper layers of the soil (Fig. 2). Similar results for silt loam soil were obtained by Watson and Kelsey (2006), who reported a significant increase in soil compaction in the layer up to $15 \mathrm{~cm}$ (5.9 inches) deep, as a result of the passing of machines.

The results of the measurement of each parts of the seedlings and parameters of needles (Table 3 ) indicate that the pressure exerted caused a significant variation of length of the primary root, arrow, and the total length of seedlings. It also affected the number of needles per seedling. However, different soil compaction did not affect the diameter of seedlings measured in the root neck and the total surface of the needles.

Analyzing the dry weight of various parts of the seedlings (Table 4), it can be concluded that the exerted pressure significantly affected the dry weight of the root system, stems, and needles, and did not affect the total dry weight of seedlings.

Change of the compactness of soil in the layer up to a depth of $15 \mathrm{~cm}$ (Table 2) induced by the exerted unit pressure caused a decrease in the length of the primary root (Fig. 3a; correlation coefficient $r=-0.46, p<0.01$ ), with a simultaneous increase in the length of stem (Fig. 3b; $r=$ $-0.35, p<0.05)$. Most likely, the seedlings compensated the hampered growth of the root system by increasing the 


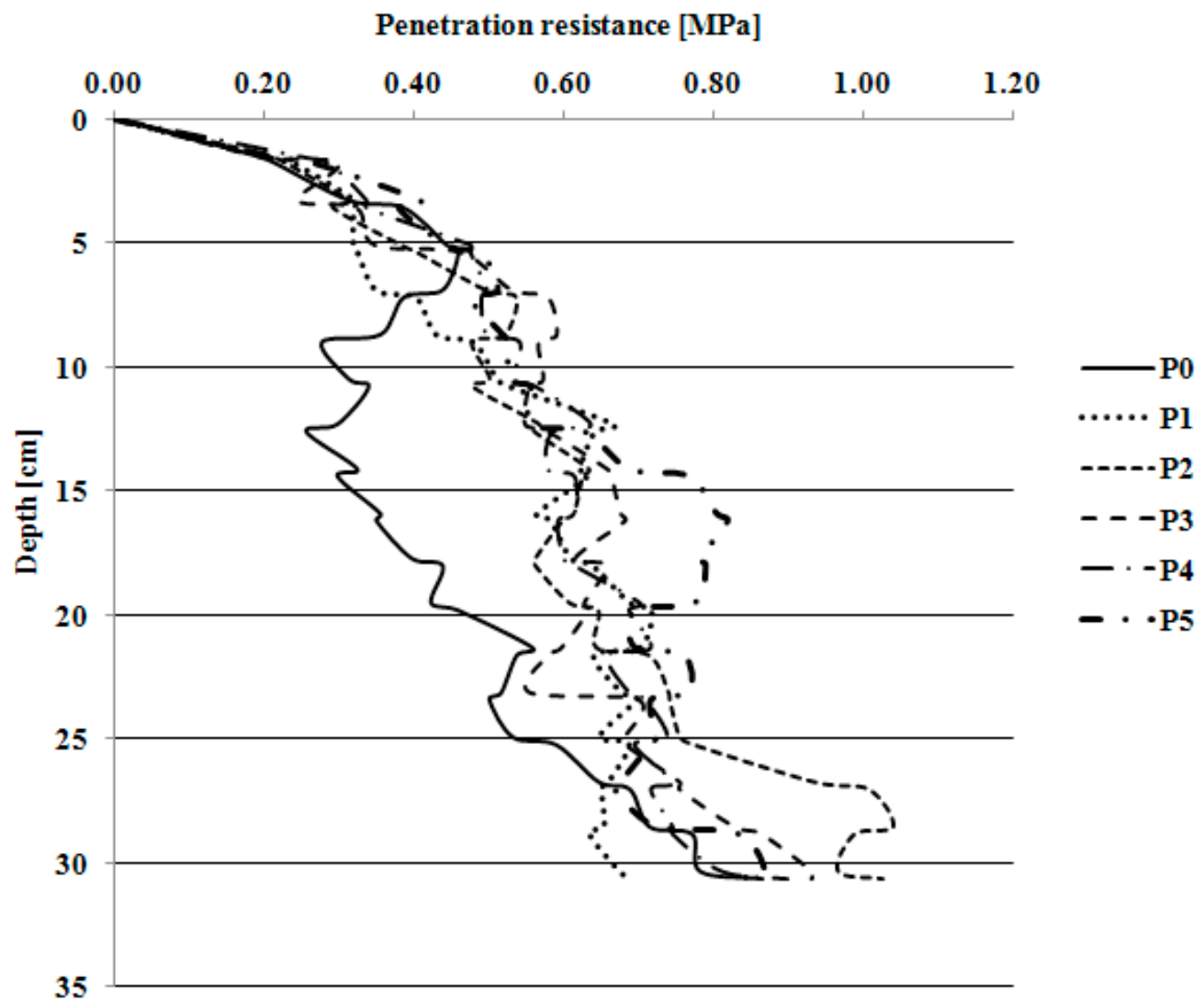

Figure 1. Change of soil penetration resistance depending on the depth and variation of pressure exerted

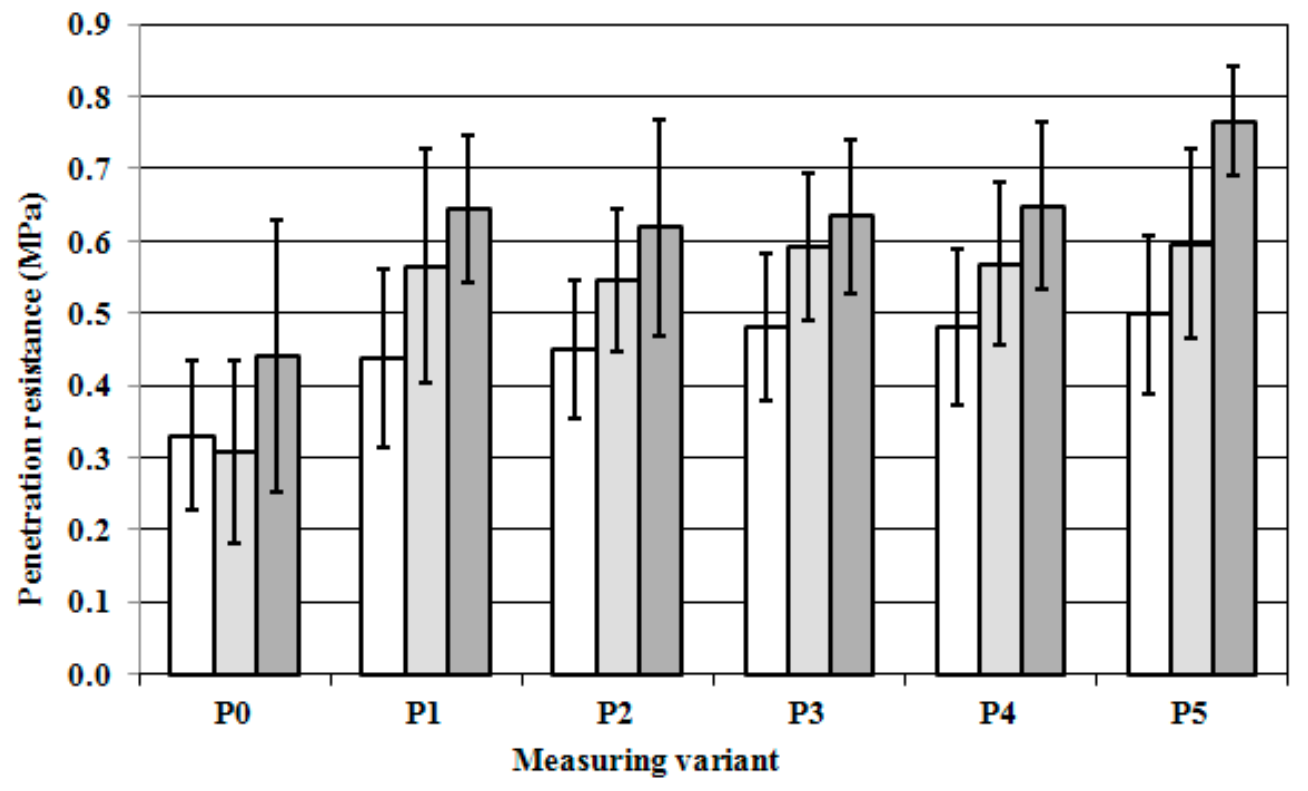

$\square 1.5-7.5 \mathrm{~cm}$ 口 $9-15 \mathrm{~cm}$ 口 $16.5-31.5 \mathrm{~cm}$

Figure 2. The average values $( \pm \mathrm{SD}$ ) of soil compactness for a 3 soil horizons depending on the pressure variant 
Table 3. Mean ( $\pm \mathrm{SE})$ values of the analyzed growth characteristics of silver fir seedlings

\begin{tabular}{|c|c|c|c|c|c|c|}
\hline \multirow[b]{2}{*}{$\begin{array}{l}\text { Measurement } \\
\text { variant }\end{array}$} & \multicolumn{3}{|c|}{ Length of } & \multirow{2}{*}{$\begin{array}{l}\text { Root collar } \\
\text { diameter } \\
(\mathrm{mm})\end{array}$} & \multicolumn{2}{|c|}{ Parameters of needles } \\
\hline & $\begin{array}{c}\text { Primary } \\
\text { root } \\
(\mathrm{cm})\end{array}$ & $\begin{array}{l}\text { Stem } \\
(\mathrm{cm})\end{array}$ & $\begin{array}{l}\text { Total seedling } \\
\qquad(\mathrm{cm})\end{array}$ & & $\begin{array}{l}\text { Number } \\
\text { (pcs) }\end{array}$ & $\begin{array}{c}\text { Total surface } \\
\left(\mathrm{cm}^{2}\right)\end{array}$ \\
\hline P0 & $9.7 \pm 2.6^{c}$ & $4.8 \pm 0.6^{\mathrm{b}}$ & $14.4 \pm 2.7^{\mathrm{c}}$ & $0.80 \pm 0.14^{\mathrm{a}}$ & $10.5 \pm 1.5^{\mathrm{a}}$ & $2.20 \pm 0.42^{\mathrm{a}}$ \\
\hline P1 & $8.9 \pm 2.7^{\mathrm{ac}}$ & $5.4 \pm 0.7^{\mathrm{ac}}$ & $14.3 \pm 1.7^{\mathrm{bc}}$ & $0.91 \pm 0.14^{\mathrm{a}}$ & $8.9 \pm 1.9^{\mathrm{ab}}$ & $2.47 \pm 0.65^{\mathrm{a}}$ \\
\hline $\mathrm{P} 2$ & $8.7 \pm 2.1^{\mathrm{ac}}$ & $4.9 \pm 0.4^{\mathrm{ab}}$ & $13.6 \pm 2.4^{\mathrm{abc}}$ & $0.80 \pm 0.13^{\mathrm{a}}$ & $9.6 \pm 2.7^{\mathrm{ab}}$ & $2.71 \pm 0.78^{a}$ \\
\hline P3 & $7.5 \pm 1.7^{\mathrm{ab}}$ & $4.9 \pm 0.5^{\mathrm{ab}}$ & $12.5 \pm 1.8^{\mathrm{ab}}$ & $0.83 \pm 0.14^{\mathrm{a}}$ & $7.8 \pm 2.0^{\mathrm{ab}}$ & $2.45 \pm 0.46^{\mathrm{a}}$ \\
\hline P4 & $7.7 \pm 1.2^{\mathrm{ab}}$ & $5.7 \pm 0.9^{c}$ & $13.4 \pm 1.5^{\mathrm{abc}}$ & $0.91 \pm 0.09^{\mathrm{a}}$ & $8.9 \pm 2.3^{\mathrm{ab}}$ & $2.32 \pm 0.47^{\mathrm{a}}$ \\
\hline P5 & $6.5 \pm 1.5^{b}$ & $5.4 \pm 0.7^{\mathrm{ac}}$ & $11.9 \pm 1.7^{\mathrm{a}}$ & $0.92 \pm 0.13^{\mathrm{a}}$ & $10.5 \pm 2.8^{\mathrm{a}}$ & $2.73 \pm 0.46^{\mathrm{a}}$ \\
\hline $\begin{array}{c}\text { Significance } \\
\text { level }(p)\end{array}$ & 0.0018 & 0.0029 & 0.0270 & 0.0514 & 0.0103 & 0.0761 \\
\hline
\end{tabular}

Different superscript letters indicate significant differences $(\mathrm{p}<0.05)$ for a parameter between measurement variants according to the post-hoc Tukey test.

Table 4. Mean $( \pm \mathrm{SE})$ values of dry weight of silver fir seedlings analyzed

\begin{tabular}{|c|c|c|c|c|}
\hline \multirow{2}{*}{ Measurement variant } & \multicolumn{4}{|c|}{ Dry mass of } \\
\cline { 2 - 5 } & $\begin{array}{c}\text { Root system } \\
(\mathrm{mg})\end{array}$ & $\begin{array}{c}\text { Stem } \\
(\mathrm{mg})\end{array}$ & $\begin{array}{c}\text { Needles } \\
(\mathrm{mg})\end{array}$ & Total seedling (mg) \\
\hline P0 & $44.4 \pm 6.3^{\mathrm{a}}$ & $22.5 \pm 5.7^{\mathrm{b}}$ & $70.5 \pm 20.1^{\mathrm{a}}$ & $137.4 \pm 24.7^{\mathrm{a}}$ \\
\hline P1 & $44.2 \pm 17.6^{\mathrm{ac}}$ & $28.6 \pm 4.0^{\mathrm{a}}$ & $81.1 \pm 21.0^{\mathrm{a}}$ & $153.9 \pm 40.5^{\mathrm{a}}$ \\
\hline P2 & $49.8 \pm 22.6^{\mathrm{a}}$ & $29.3 \pm 4.9^{\mathrm{a}}$ & $82.2 \pm 23.8^{\mathrm{a}}$ & $161.3 \pm 45.5^{\mathrm{a}}$ \\
\hline P3 & $30.3 \pm 15.8^{\mathrm{b}}$ & $21.3 \pm 7.9^{\mathrm{b}}$ & $64.7 \pm 21.9^{\mathrm{a}}$ & $116.3 \pm 42.0^{\mathrm{a}}$ \\
\hline P4 & $39.5 \pm 11.3^{\mathrm{abc}}$ & $29.7 \pm 8.5^{\mathrm{a}}$ & $43.9 \pm 18.9^{\mathrm{a}}$ & $133.1 \pm 28.5^{\mathrm{a}}$ \\
\hline P5 & $32.2 \pm 10.0^{\mathrm{bc}}$ & $28.2 \pm 4.9^{\mathrm{a}}$ & $77.8 \pm 13.9^{\mathrm{a}}$ & $138.3 \pm 22.7^{\mathrm{a}}$ \\
\hline Significance level $(p)$ & 0.0073 & 0.019 & 0.1909 & 0.0676 \\
\hline
\end{tabular}

Different superscript letters indicate significant differences $(\mathrm{p}<0.05)$ for a parameter between measurement variants according to the post-hoc Tukey test.

length of the stem, although the total length of the seedling decreased with an increase in soil compaction (Fig. 3c; $r=$ $-0.35, p<0.05$ ). Moreover, the number of needles on seedlings decreased (Fig. 3d; $r=-0.27, p<0.05$ ).

A decrease in the length of the primary root has already been observed by Sands and Bowen (1978) for the growth of Monterey pine (Pinus radiata D. Don) seedlings on the compacted soil, as well as by Corns (1988) for the growth of seedlings of lodgepole pine (Pinus contorta Dougl. ex Loud.) and white spruce (Picea glauca (Moench) Voss). Reduction in the number of roots in the case of large trees (breast height diameter at $30 \mathrm{~cm}$ ) of pin oak (Quercus palustris Münchh.) has also been reported by Watson and
Kelsey (2006). A decrease of the rate of diffusion of oxygen in the spring caused by the compaction of a topsoil due to passing of machines is a primary cause of this phenomenon. However, Watson and Kelsey (2006) reported no growth of the thickness (breast height diameter) of leaf surface, growth of branches, or tree dying in the studies.

The plot figure presenting the changes in the dry weight of various parts of seedlings along with the change of penetration resistance (Fig. 4) clearly indicates a decrease in the dry weight of the root system (Fig. 4a; $r=-0.29, p<$ 0.05 ) and an increase in the dry weight of a stem (Fig. 4b; $r=0.26, p<0.05$ ). Similar results regarding decrease of the total dry weight of seedling and dry weight of its root 

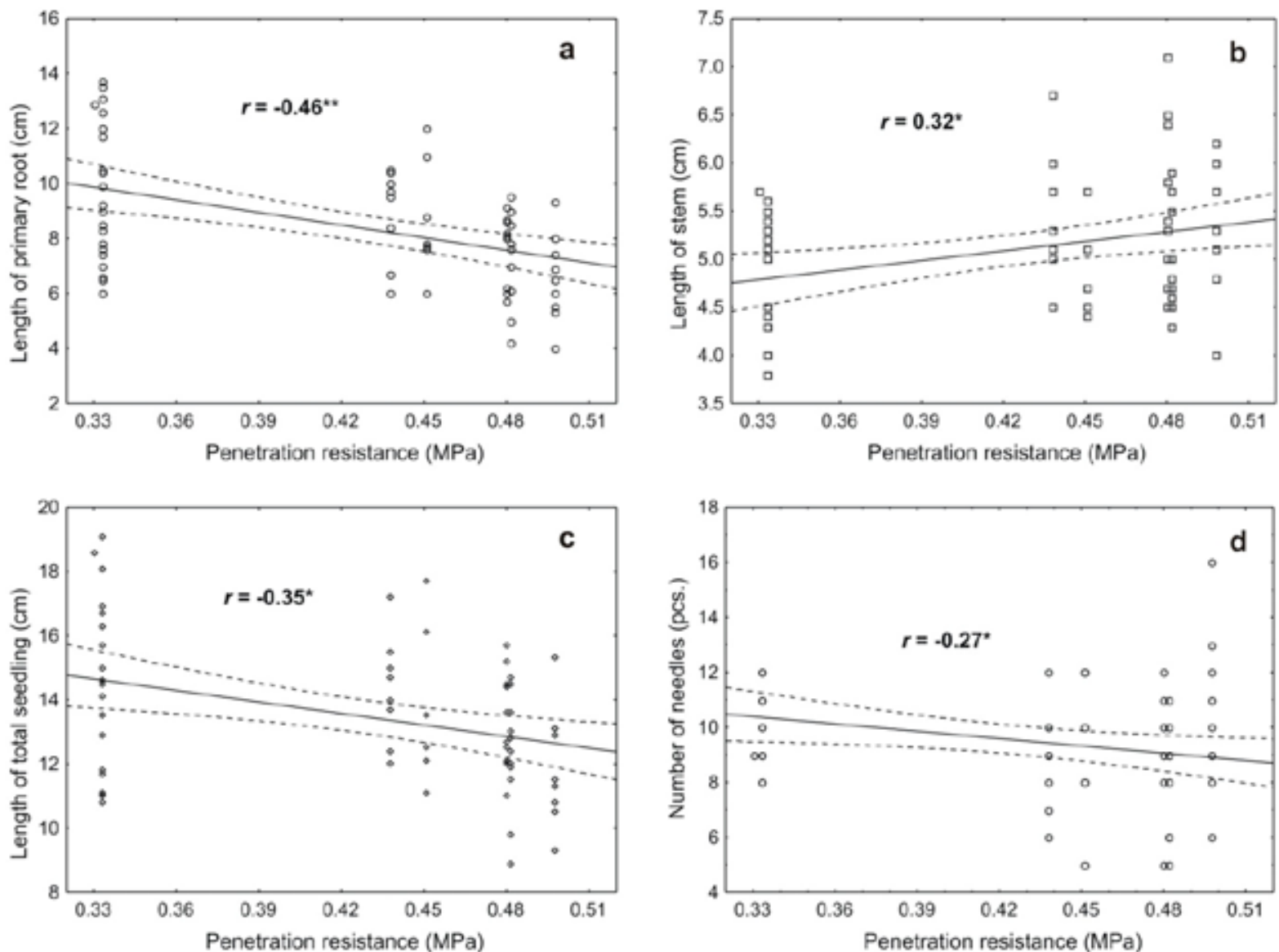

Figure 3. The effect of soil compaction on growth parameters and needles number of seedlings. The correlation coefficient was presented with the level of significance: $* p<0.05 ; * * p<0.01$
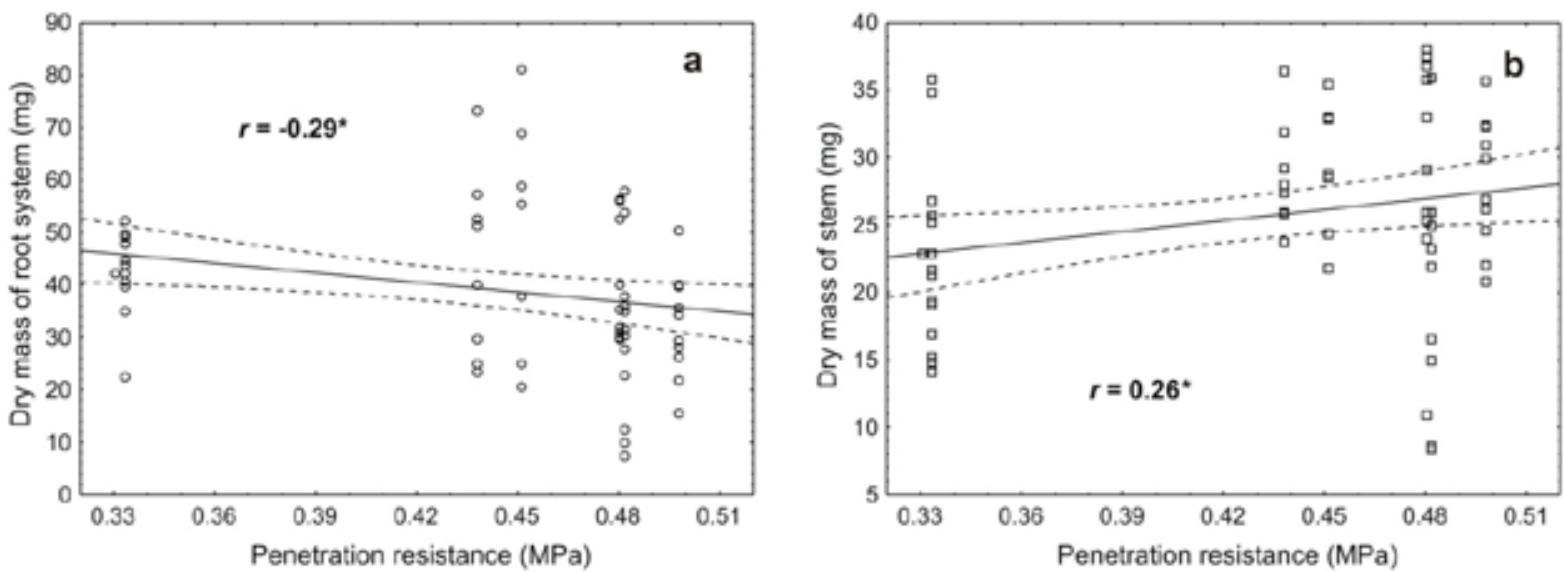

Figure 4. The influence of soil compaction on the parameters of the dry weight of seedlings. The correlation coefficients were presented with the level of significance: $* p<0.05$ 
system were reported by Corns (1988) for lodgepole pine (Pinus contorta) and white spruce (Picea glauca) growing on compacted soil. The change in the dry weight of needles was not significantly correlated with the change of soil compaction.

\section{Conclusions}

1. Increasing the unit pressure (in the range of 50-250 $\mathrm{kPa}$ ) applied on the soil resulted in an increase in soil compaction, as indicated by the increase in the compactness of the soil in a layer up to $15 \mathrm{~cm}$ deep, which contained the root of silver fir (Abies alba Mill.) seedlings. The application of pressure also influenced the increase in compaction in the deeper layers of the soil (up to the investigated depth of $31.5 \mathrm{~cm}$ ).

2. The changes of soil compaction caused by the different value of exerted unit pressure significantly affected the diversity of the following parameters: length of the primary roots, stems, total number of seedlings, number of needles, dry weight of the root system and stem. However, it did not affect the diameter of the root collar, the surface of assimilation apparatus, the dry weight of the whole seedling and the dry weight of assimilation apparatus.

3. There was a statistically significant negative correlation between the increase in soil compaction expressed by penetration resistance and the length of the primary root $(r=-0.46)$, the total length of seedlings $(-0.35)$, and the dry weight of the root system $(-0.29)$, and a positive correlation between the length $(0.32)$ and the dry weight of the stem $(0.26)$. The relationship proved to be statistically insignificant in the case of the dry weight of assimilation apparatus.

\section{Acknowledgements}

The research paper was funded by grants awarded by the Ministry of Science and Higher Education (DS-3401/ KMPL and DS-3405/ZGNiSzL). The authors also want to thank workers of the Niepołomice Forest Division for sharing the research area.

\section{References}

ASAE Standards, 1998, Soil Cone Penetrometer, [in:] Standards Engineering Practices Data, American Society of Agricultural Engineers, 820-821.

Alameda D., Anten N. P. R. \& Villar R., 2012, Soil compaction effects on growth and root traits of tobacco de- pend on light, water regime and mechanical stress, Soil \& Tillage Research 120: 121-129.

Blouin V. M., Schmidt M. G., Bulmer C.E. \& Krzic M., 2008, Effects of compaction and water content on lodgepole pine sidling growth, Forest Ecology and Management 255: 2444-2452.

Bejarano M.D., Villar R., Murillo A.M. \& Quero J.L., 2010, Effects of soil compaction and light on growth of Quercus pyrenaica Willd. (Fagaceae) seedlings, Soil \& Tillage Research 110: 108-114.

Conlin T.S.S. \& van den Driessche R., 1996, Short term effects of soil compaction on growth of Pinus contorta seedlings, Canadian Journal of Forest Research 26: 727-739.

Corns I.G.W., 1988, Compaction by forestry equipment and effects on coniferous seedling growth on four soils in the Alberta foothills, Canadian Journal of Forest Research 18: 75-84.

Dexter A.E., Czyż E.A. \& Gate O.P., 2007, A method for prediction of soil penetration resistance, Soil \& Tillage Research 93 (2): 412-419.

Kormanek M., 2011, Mobile hand-held cone penetrometer with data logger, Polish patent application: P.397565.

Kormanek M., 2013, Tractor device to exert controlled pressure on the ground, Polish utility model: W.120048.

Kormanek M. \& Banach J., 2012, Influence of unit pressure exerted on soil on quality of renewal of chosen species of trees, Acta Agrophysica 19(1): 51-63.

Kormanek M., Banach J. \& Ryba M. 2013, Influence of substrate compaction in nursery containers on the growth of Scots pine (Pinus sylvestris L.) seedlings, Leśne Prace Badawcze 74 (4): 307-314.

Kozlowski T. 1999, Soil compaction and growth of woody plants, Scandinavian Journal of Forest Research 14: 596-619.

Lipiec J., Hajnos M. \& Świeboda R., 2012, Estimating effects of compaction on pore size distribution of soil aggregates by merkury porosimeter, Geoderma 179180: 20-27.

Maupin C. \& Struve D.K., 1997, Red oak transplanting to different bulk density soils have similar water use characteristics, Journal of Arboriculture 23: 233-238.

Pérez-Ramos, I.M., Gómez-Aparicio, L., Villar, R., García, L.V. \& Marañón, T., 2010, Seedling growth and morphology of three oak species along field resource gradients and seed-mass variation: a seedling-age-dependent response, J. Veg. Sci. 21: 419-437.

PTG, 2008, Klasyfikacja uziarnienia gleb i utworów mineralnych [Classification of grain-size composition of soils and mineral sediments], Polish Society of Soil Science.

Picchio R., Neri F., Petrini E., Verani S., Marchi E. \& Certini G., 2012, Machinery-induced soil compaction in 
thinning two pine stands in central Italy, Forest Ecology and Management 285: 38-43.

Sack L., 2004, Responses of temperate woody seedlings to shade and drought: dotrade-offs limit potential niche differentiation?, Oikos 107: 110-127.

Sands R. \& Bowen G.D., 1978, Compaction of sandy soil in radiate pine forests. 2 . Effects of compaction on root configuration and growth of radiata pine seedlings, Australian Forest Research 8: 163-170.

Sobczak R. (ed.), 1992, Szkółkarstwo leśne [Forest tree seedling nursery], Wydawnictwo Świat, Warszawa.
Ulrich R., Neruda J. \& Valenta J., 2003, Wpływ układów jezdnych wybranych maszyn maszyn na glebę [Effects of the machines running gears on soil], Inżynieria Rolnicza 7(11): 229-235.

Watson G.W. \& Kelsey P., 2006, The impact of soil compaction on soil aeration and fine root density of Quercus palustris, Urban Forestry \& Urban Greening 4: 69 -74 .

Zahreddine H.G., Struve D.K. \& Quigley M., 2004, Growing Pinus nigra seedlings in Spinout-treated containers reduces root malformation and increases regrowth potential, Journal of Environmental Horticulture 22:176182. 